\title{
Should Albania allow the construction of nuclear power plants for electricity - production?
}

\author{
Ma. Aleks Palnikaj ${ }^{1}$
}

\begin{abstract}
The development of the energy sector is one of the main factors that affect the general economic development of a country. In this context, it is one of the most important factors that influence, in the foreign investment.

Albania has faced with problems in power sector during these years, because of our electricity resources are provided by $98 \%$ of water resources. So Albania is a country entirely dependent on rainfall. Recent changes: global climate; increasing fuel prices; rapid growth of demand for electricity consumption; technological changes and the rising cost of electricity require the development of new policies in the energy sector.

This study aims to identify these factors that affect the production of electricity in our country, opportunities that Albania has in this area and the efficiency of their use.

Building a nuclear power plant in Albania is seen as a new opportunity for the sustainable development of the power sector.
\end{abstract}

\section{Introduction}

Economic development of the country and transformation of Albania as an attractive region to foreign investment, have raised new challenges in the energy sector. The main issues of security of supply, new electricity sources to suffice the country request, electricity achieved at low cost, reduce of electricity losses, guaranteed service and easy access to every business and every family are in the everyday focus of the electricity market reform.

Albania transfers monetary amounts abroad every year and this directly affect its trade balance and the lack of electricity leads to endangering economic independence.

Albania aspires to become soon member of the European Union. So there are some obligations to complete before adhering EU, also in energy sector. One important goal is the liberalization of electricity market, which cannot permit outage of service and discontinuity in supply.

${ }^{1}$ Albanian Power Corporation, Economic Department. PhD candidate in Economics and Sustainable Development at the European University of Tirana, Albania 
The $50 \%$ of country electricity demand is fulfilled from abroad, while electricity demand is growing at $4-6 \%$ per year.

Recent changes in:

- Global climate;

- Successive crises of electricity in the country;

- Increased fuel prices and rapid exhaustion of their region and beyond;

- Problems of nuclear reactors in Japan and Bulgaria and their impact on public opinion regarding nuclear production;

- Technological changes and increased electricity prices;

- Orientation increasingly more global policies towards renewable energy, have made the necessary revision of national policies and strategies for energy.

This paper aims to study these factors and other factors that affect the production of electricity in the country, opportunities that the country has in this area and the efficiency of their use.

How many opportunities has the country to cope with the increasing demand of electricity being adapted and applied the laws of EU countries in which Albania wants to join?

Does Albania has ability and capacity for operating and utilizing the numerous resources in this area.

\section{Albania power background.}

Albania lays down in South East Europe and has a total area of 28,748 square kilometers. It is ranked as a place with notably hydro power sources. Albania has a major hydropower potential, which only $35 \%$ of it has been exploited up to date. Profitability of hydropower exploitation is conditioned by hydrological conditions, geological, for the construction of dams and particularly by topographical conditions in view of avoiding as much as possible flood risk land. Hydropower plants construction also depends on the large initial investment per unit as well as the possibility to adjust the flow in high level creating cumulative reservoir.

The $70 \%$ of country area is mountainous, rugged and often inaccessible from the outside.

Albania has a hydrographic area of 44,000 square kilometers, thinking that some water sources includes territories outside the official boundaries of the state which are more than $57 \%$ of the state area.

Rainfall averages from 1,000 millimeters (39.4 in) to more than 1,500 millimeters (59.1) annually, with the higher levels in the north. Nearly $95 \%$ of the rain falls in winter. Rainfall in the upland mountains is heavier. Adequate records are not available but annual averages are probably about 1,800 millimeters (70.9 in) and are as high as 2,550 millimeters (100.4 in) in some northern areas. The western 
Albanian Alps (Valley of Boga) are among the western areas in Europe receiving 3,100 millimeters (122.0 in) of rain annually. Snow falls at altitudes above 1,000 meters and in higher mountainous places does not melt for months fitting out the river in spring time even in summer.

Rainfalls are not the same during the year and therefore the flow of rivers change during the year.

Albanian power sector relies on hydropower with proportion of more than $90 \%$ of total generation capacities. Actually, hydropower installed capacity is 1726.8 MWh, from that 1403 MWh capacity is installed in waterfall of Drin River where are four power stations Fierza, Koma, Vau Dejes, Ashta. The Fierza HPP has the biggest reservoir and can store up 1.4 TWh. The rest is installed in Mat river, Bistrica river and some small hydropower plants which are built along the county. Multi average production of hydropower is 5,114 GWh per year. Exploitation of hydro resources is conditioned by hydrological factors.

Total hydropower resources are estimated around 3,000 $\mathrm{MWh}$ and additional annual potential output can reach $10-12$ TWh. Actually, given that the $95 \%$ of hydropower plants lie in north of Albania, is recommended the establishment of new power plants in southern part of Albania (Vjosa river, Devolli river) because it will make possible geographic balance production with the demand. Based on the work of the Institute of Studies and Design Hydrotechnical Works, it made possible a preliminary determination full scheme of Drini river usage, Devolli river usage and Vjosa river usage : Average annual production is 5,11 4,000,000 KWh.

\section{Country's demand for electricity.}

Electricity consumption continues to grow by about $5.7 \%$ per year reaching $7,342,000 \mathrm{KWh}$ considering that in recent years power interruption was almost zero.

Albanian government continues to give importance to the construction of hydropower plants. This reality is reflected in the increasing number of construction small and medium hydropower plants in the country. But the question is:

Is this the final solution for the provision of electricity to end customers? 


\begin{tabular}{|c|c|c|c|c|c|c|c|c|c|}
\hline \multirow{2}{*}{$\begin{array}{c}\text { Power Plant } \\
\text { Features }\end{array}$} & \multicolumn{10}{|c|}{ PUBLIC POW } \\
\cline { 2 - 10 } & HPP & $\begin{array}{c}\text { Koman } \\
\text { HPP }\end{array}$ & $\begin{array}{c}\text { V.Dejes } \\
\text { HPP }\end{array}$ & $\begin{array}{c}\text { Ulez } \\
\text { HPP }\end{array}$ & $\begin{array}{c}\text { Shkopet } \\
\text { HPP }\end{array}$ & $\begin{array}{c}\text { Bistr.1 } \\
\text { HPP }\end{array}$ & $\begin{array}{c}\text { Bistr.2 } \\
\text { HPP }\end{array}$ & $\begin{array}{c}\text { LanaBregas } \\
\text { HPP }\end{array}$ & $\begin{array}{c}\text { Vlora } \\
\text { TPP }\end{array}$ \\
\hline $\begin{array}{c}\text { Number } \\
\text { of Units }\end{array}$ & 4 & 4 & 5 & 4 & 2 & 3 & 1 & 2 & 2 \\
\hline $\begin{array}{c}\text { Capacity } \\
\text { of Units }\end{array}$ & 125 & 150 & 50 & 6.3 & 12 & 7.7 & 5 & 2.5 & $70+28$ \\
\hline $\begin{array}{c}\text { Installed } \\
\text { Capacity (MW) }\end{array}$ & 500 & 600 & 250 & 25 & 24 & 24 & 5 & 5 & 98 \\
\hline $\begin{array}{c}\text { Total Installed } \\
\text { Capacity (MW) }\end{array}$ & \multicolumn{10}{|c|}{$\mathbf{1 , 5 3 1}$} \\
\hline
\end{tabular}

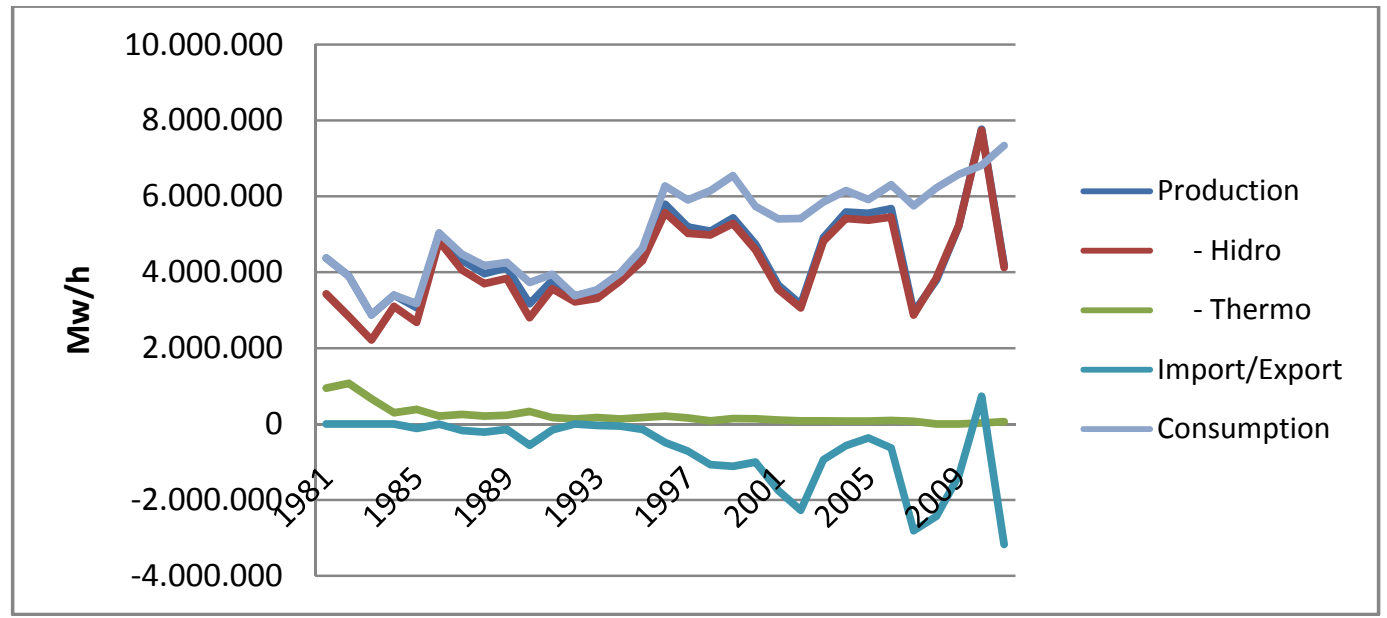

Figure 1. Production - Consumption - Import/Export 1981-2011

(Source: KESH sh.a.)

As stated from above, Albania has no diversification in electricity sources thus is entirely dependent on meteorological conditions. To reduce dependence on rainfall, the country needs to build new capacity for electricity production.

Country's needs for electricity do not go parallel with climate change. Demand for electricity increases significantly by the use of air conditioners and mainly coastal tourism in summer but on the other hand reduced our opportunity through existing hydropower production. At the same time increased electricity imports prices reaching maximum values.

\begin{tabular}{lllllll}
\hline Viti & Installed & Added & Total & Growth $\%$ & Production & \# of Production \\
& MW & MW & MW & & & \\
2007 & 1,432 & 0 & 1,432 & $0 \%$ & $2,874,362$ & $-47 \%$ \\
2008 & 1,432 & 18 & 1,450 & $1.26 \%$ & $3,849,893$ & $34 \%$ \\
2009 & 1,450 & 12 & 1,462 & $0.84 \%$ & $5,229,618$ & $36 \%$ \\
2010 & 1,462 & 11 & 1,473 & $0.77 \%$ & $7,714,546$ & $48 \%$ \\
2011 & 1,473 & 10 & 1,483 & $0.65 \%$ & $4,126,549$ & $-47 \%$ \\
\hline
\end{tabular}


Table 2. Total Capacity of Albania public power plant (Source: ERE. Anual Report 2011)

As shown in the table above increased power installed in Albania is around 7\% and overall production does not increase in the same proportion.

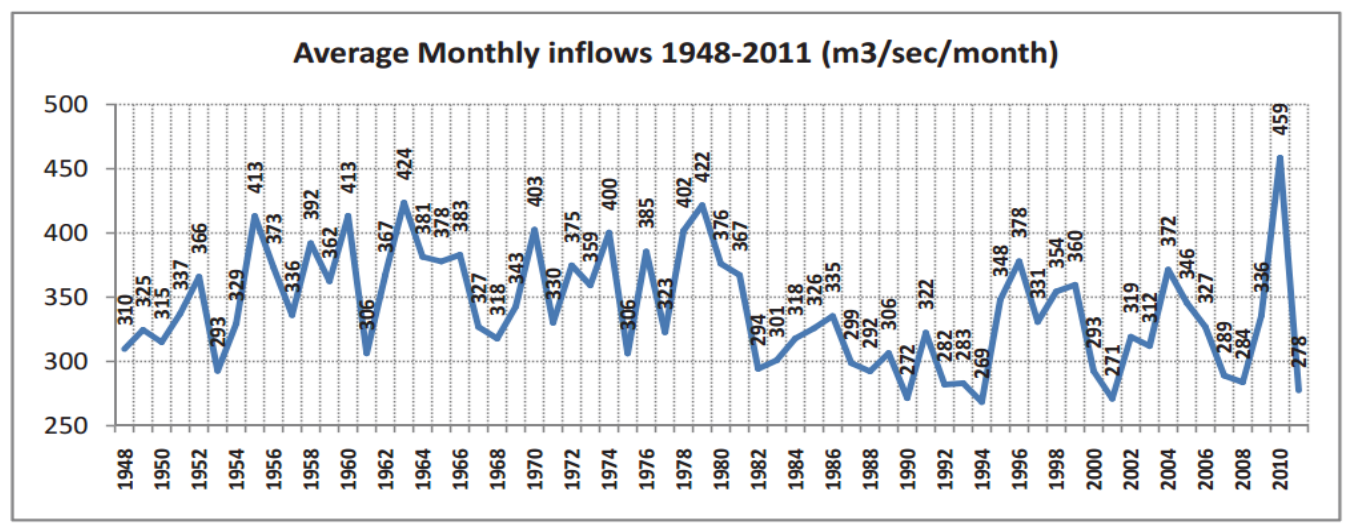

Figure 2 Average monthly inflows in Fierza HPP, monthly average for 1948-2011

* Source ERE

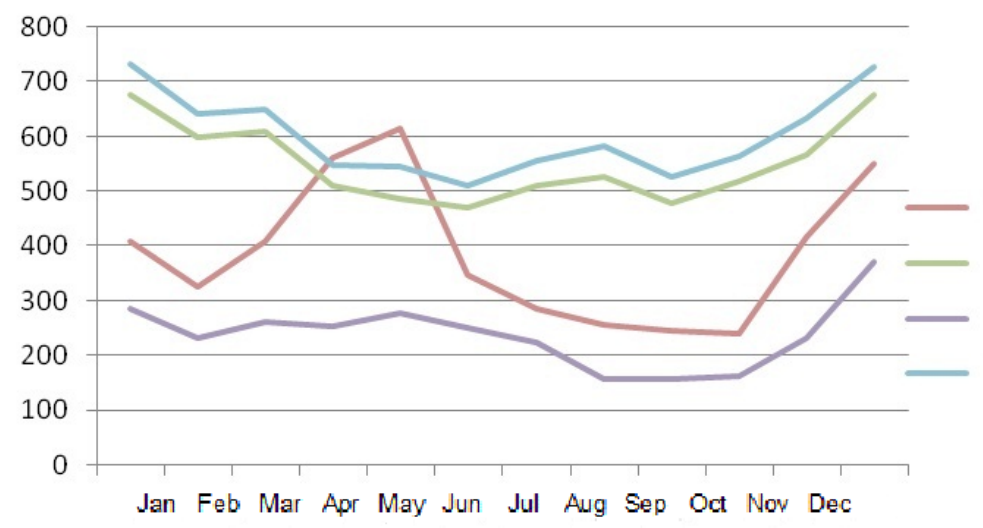

Average production

Average consumption

Minimal production ( 2007)

Maximum production ( 2011)

Figure 3 Average production, consumption, minimal and maximal

(Source: ERE,2011)

From the chart above we notice a very big difference between maximal consumption and minimal production of the country in years, a difference which must be provided if requested maximum security in the supply of the population with electricity. It should be noted that even if the total amount of annual production may be equal to the annual consumption still it cannot say that is provided sufficient energy to meet the needs of the country, as energy is a product that cannot be reserved but it must be produced at the time that is required. Frequent fluctuations in short-term periods are governed by balancing 
energy use in plants as the same amount can be provided by changing water levels in lakes. But what can be done in the long term?

1. Increasing import-export opportunities by building new interconnection lines especially with Kosovo, Former Yugoslav Republic of Macedonia and Italy. But the cost will be very high again, because we will have to sell power in many cases in high rainfall periods when the price is very low and will buy in drought periods when the import price peaks.

2. Diversification of electricity resources by building others electricity production capacity mainly that does not depend on the country's climate. There are some alternative:

- Construction of termopower plants that operate with:

o Oil, gas; o Coal; o Solar; o Etc.

In order to increase the security of electricity supply for consumers, country currently needs an additional capacity, at much lower cost, to the extent of 500 MW. This added capacity ensures uninterrupted production of electricity and independent of weather factors.

(7.342 to 2.874 ) / 12 months / 30 days / 24 hours $\approx 500 \mathrm{MW}$

Albania should have this additional capacity to provide maximum power supply.

Domestic consumption will continue to grow by at least $5.7 \%$ will take the average growth in the years 1985-2011

\begin{tabular}{|l|l|l|l|l|}
\hline Year & 2008 & 2009 & 2010 & 2011 \\
\hline Consumption & $6,223,752$ & $6,584,716$ & $6,821,306$ & $7,342,000$ \\
\hline Growth & & $5.8 \%$ & $3.6 \%$ & $7.6 \%$ \\
\hline
\end{tabular}

Table 3 Electricity Production 2008-2011

The evidences suggest that construction of Oil and Gas power plants in Albania currently is not efficient (TPP in Vlora) due to the high price of oil. The new power plant in Vlora build in 2009 has an installed capacity of $98 \mathrm{MWh}$ operates for short periods during the year because the cost of $1 \mathrm{KWh}$ is too high, depending on the oil price. 


\section{Construction of nuclear plants.}

Nuclear power is classified as a clean one which advantage is producing electricity at low cost and in very large quantities. Many countries are oriented towards cleaner sources of electricity as the fuel prices is going up and the quantity of $\mathrm{C} 2 \mathrm{O}$ to the atmosphere is increasing every day more.

\begin{tabular}{|c|c|c|c|c|c|c|c|}
\hline & 1980 & 2009 & 2015 & 2020 & 2030 & 2035 & $2009-2035^{*}$ \\
\hline Coal & 1792 & 3294 & 3944 & 4083 & 4099 & 4101 & $0.8 \%$ \\
\hline Oil & 3097 & 3987 & 4322 & 4384 & 4546 & 4645 & $0.6 \%$ \\
\hline Gas & 1234 & 2539 & 2945 & 3214 & 3698 & 3928 & $1.7 \%$ \\
\hline Nuclear & 186 & 703 & 796 & 929 & 1128 & 1212 & $2.1 \%$ \\
\hline Hydro & 148 & 280 & 334 & 377 & 450 & 475 & $2.1 \%$ \\
\hline Biomass and waste & 749 & 1230 & 1375 & 1495 & 1761 & 1911 & $1.7 \%$ \\
\hline Other renewables & 12 & 99 & 197 & 287 & 524 & 690 & $7.8 \%$ \\
\hline Total & 7219 & 12132 & 13913 & 14769 & 16206 & 16961 & $1.3 \%$ \\
\hline
\end{tabular}

Table 4. Forecast of world production of energy

(Source: World Energy Outlook 2011)

Construction of a nuclear reactor to fulfill the country's demand for electricity.

Building a nuclear reactor for electricity production, first of all requires e creation of a suitable infrastructure including a number of measures.

There are about 439 reactors worldwide, which enable the production of a significant amount of electricity and it is expected to reach its maximum in the period 2010-2015. The main reason for the trend in the decline of electricity production from nuclear power plants is that over 82 percent of these plants are already 17 to 30 years in use, while the average time of one such installation varies in about 40 years.

Nuclear power plants are compact installations. They offer large capacity and electricity production with the construction of a plant with a capacity of 1,000 MW, or even the two power plants of $600 \mathrm{MW}$ each; of course, the production capacity of electricity in Albania can be doubled or triple.

But is this a real possibility?

The main conditions needed for the construction of a nuclear power plant:

First, to build a nuclear power plant with a capacity of 1,000 MW will be about 1 to 2 billion euros, 
It is needed a considerable amount of physical time to construct a plant (after taking a political decision to start the operation of a plant nuclear required at least 10 to 15 years).

Preparation of an adequate legal framework and determination of the specific institutions that will realize implementation of laws.

Preparation of human potential that includes education, specialization.

Construction of new transmission lines for electricity. Meanwhile, another major difficulty for the nuclear option in Albania relates to the possibility of introducing a nuclear power plant after the country's electricity network, as a rule, increased capacity for electricity production should not exceed more than 10 percent of existing capacity, while building and making use of a nuclear power plant with minimum capacity of 400-600 MW nearly double this capacity.

Other impeding factors are the lack of stability of the coastline, the high level of seismic country, licensing regulatory infrastructure, deficient legal framework.

The experience of developed countries shows that the construction of a nuclear reactor takes at least 7-8 years, which means that if the construction of his starts this year, will start production at least in 2020 when domestic consumption is expected to be10.450 MWh.

Table 5 Forecast of Albania production of energy

\begin{tabular}{|l|l|l|l|l|l|l|l|l|l|}
\hline Year & 2012 & 2013 & 2014 & 2015 & 2016 & 2017 & 2018 & 2019 & 2020 \\
\hline Consumption & 7,731 & 8,141 & 8,572 & 9,027 & 9,505 & 10,009 & 10,539 & 11,098 & 11,686 \\
\hline
\end{tabular}

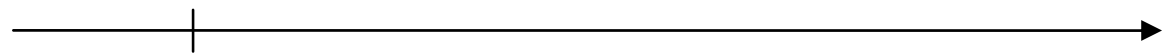

The above, the need for the country's generating capacity will be:

$500 \mathrm{MW}+(11,686$ to 7.342$) / 12$ months / 30 days / 24 hours $\approx 1000 \mathrm{MW}$

additional installed power.

And this is the additional capacity should build Albania to ensure power supply to 2020 .

Current proven world reserves of uranium are sufficient to supply current global demand for 50 years.

Operating cost includes a charge of 0.2 cents per KW-Hr to fund the eventual removal of waste from the reactor and reactor decommissioning. The price of uranium ore contributes about 0.05 cents per $\mathrm{kWh}$.

According to studies, if a Nuclear Power with $\$ 1,500$ per kilowatt capital investment, the cost of electricity that is produced will be in about 3 U.S. cents $\mathrm{kWh}$ 
Nuclear:

$\$ 0.019$

Coal:

Natural Gas :

Wind:

Hydroelectric:

Nuclear power is unique in that it has to pay for the decommissioning of the facility's future. Decommissioning costs vary from year to year depending on changes in the return on investment from the fund, but a general guideline is $\$$ 0.0015 per $\mathrm{kWh}$. This cost per $\mathrm{kWh}$ gives a $\$ 500,000,000$ fund for dismantling if we get a $4 \%$ return rate on investment over 40 years (useful life)

It is certainly that this cost, is several times higher, including all the hidden costs that have to do with preparing the external field to the building such as: awareness of the population, studying area away from residential centers and areas with low seismic. Cost, this according to the experiences of other countries, reaches between $\$ 3,600$ and $\$ 6,000$ per installed $\mathrm{kW}$.

Nuclear accidents events, including that of Fukushima, have raised the demand for new technology, which is still in the experimental stage and is expected to appear on the market in early 2030. Precisely for this reason, many countries experienced in nuclear energy "stop" the construction of new power plants and are waiting for the technology of the future. Albania has enough time to assess the possibilities and to review carefully the option of producing nuclear electricity.

\section{Conclusion}

Albania though too late should pave the way for the construction of nuclear power plants.

Construction of manufacturing plants should proceed in two directions:

1. To exploit the maximum available resources for power production.

2. To increase the security of supply of electricity for the population through the diversity of production mainly producing clean energy and independent of weather conditions.

\section{Advantages}

- Nuclear power is a clean one, without polluting emissions of greenhouse gases.

- Nuclear power plants have high efficiency.

- Unlike renewable, nuclear power is independent of weather conditions.

\section{$\underline{\text { Disadvantages }}$}

Nuclear fuels are non-renewable resources and one day they will exhaust. 
Radioactive waste management is difficult. Their radiation continues for thousands of years, which is dangerous for health.

Nuclear fuels have high explosive properties, which brings high risk of potential accidents and nuclear terrorist attacks.

Building nuclear plants is relatively expensive, especially for the economic conditions of the country.

Albania is currently unprepared to implement this kind of technology that, according to this study is the only way out of the energy crisis and not only keep the hope of rain. It has enough time to assess the possibilities and to review carefully the option of producing nuclear electricity.

\section{References}

Albanian Energy Regulator (ERE) Annual Report_2011

Albanian Power Corporation KESH sha.

CEZ Supply sha.

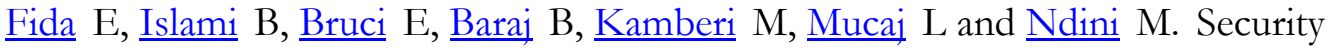
Of The Energy Sector In Albania In The Face Of Climate Change "ENERGY AND ENVIRONMENTAL CHALLENGES TO SECURITY".

Karaj Sh. Rebl T, Leis H, Muller J "Analysis of biomass residues potential for electrical energy generation in Albania"- Renewable and Sustainable Energy Reviews Volume 14, Issue 1, January 2010.

Ministry of Economy, Trade and Energy (METE)

World energetic outlook 2011 IEA. 